extension of the survey of the Algæ and algal resources of Philippine and Indonesian waters to cover the Pacific, and the establishment of a scientific centre in the Philippines, supported by private funds.

\section{FREE-PISTON COMPRESSOR-ENGINES}

$\mathrm{T}$ HE paper by H. O. Farmer on "Free-Piston Compressor-Engines", read before the Institution of Mechanical Engineers on December 6, must have been for many their first introduction to the subject, as this type of engine has received little publicity and has only just reached the production stage.

The free-piston compressor-engine, in its production form, is a reciprocating air compressor driven by a reciprocating two-stroke compression-ignition (or Diesel) engine. The outstanding feature is that neither the engine nor the compressor has the conventional rotating crankshaft; instead, the engine and compressor cylinders are arranged in line and the pistons are coupled directly. A normal engine has a flywheel which supplies the energy for the compression stroke; but in the free-piston engine, which has no flywheel, energy is supplied by the compressed air remaining in the compressor cylinder clearance space. This action is assisted in most free-piston engines by a separate 'cushion' cylinder with a closed end.

In order to improve the balance, there is usually a piston at each end of the engine cylinder, one being coupled directly to the compressor piston and the other to the 'cushion' piston; these two moving systems are coupled by a light linkage so that their displacements are equal and opposite. The underside of the compressor piston is used to pump scavenging air for the engine cylinder. This arrangement has all the very attractive features of the opposed-piston, two-stroke, supercharged, compression-ignition engine without the complication and expense of the connecting rods and rotating parts associated with conventional designs.

The amount of fuel injected is varied automatically by a governor so as to keep the output air pressure constant; the effect of varying the air demand being to change the stroke of the plant (the stroke is not fixed as in a normal plant). The frequency of the cycles remains nearly constant, and is 1,000 cycles per minute in one case quoted in the paper.

Starting is accomplished by bringing the engine pistons together suddenly. In small engines this is done by a spring, previously compressed manually through a handle and gearing; in larger engines a charge of compressed air is admitted to the 'cushion' cylinder. Another interesting detail is the method of driving rotating accessories such as the cooling fan and the water pump; the main reciprocating parts drive a plunger-type oil pump; this oil then drives a gear-type oil motor which provides the small power required.

A possibility which is being actively investigated is the use of a free-piston compressor-engine, instead of the usual rotary air compressor, in conjunction with a gas turbine for power purposes. The whole of the air pumped by the compressor cylinder is fed to the engine cylinder for scavenging and super. charging, and the hot exhaust gas, at comparatively high pressure, passes through a gas turbine. It is claimed that the very high overall efficiency of 41 per cent is obtainable.

Free-piston compressor-engines were largely developed by Pescara, who started work on them in France in 1922. In Great Britain their development was encouraged by the Services; the first engines were ordered for the Navy and later ones for the Army.

\section{TREPHOCYTES AND TREPHOCYTOSIS}

$\mathrm{D}^{\mathrm{n}}$ R.LIEBMAN'S monograph, "On Trephocytes and Trephocytosis; a Study on the Role of Leucocytes in Nutrition and Growth" (Growth, 10, 291; 1946), concerns a neglected field of invertebrate hæmatology, and combines a comprehensive review of the literature with a record of his own extensive studies. Attention is focused on leucocytic elements that contain inclusion bodies (granules, spherules and pigment), but which, according to the evidence, have no phagocytic function. The author advances a wellsubstantiated view that the inclusion bodies are elaborated inside these cells, which he calls 'trephocytes', and that they are discharged and utilized as nutrient material in regions of increased metabolic activity. Hence the concept of trephocytosis, which is thought to be the main function of these cells, as opposed to phagocytosis, which, in the author's opinion, may well be the main task of hyaline 'lymphoidocytes'. On the comparative side, a parallel is drawn between the trephocytes of invertebrates and the mast cells of vertebrates.

The attitude of the author is characterized by a justified reluctance to apply, without reservation, the teleological line of thought imposed by mammalian 'defence' physiology and, consequently, a caution in attributing phagocytic properties to elements which do not seem to possess any.

Of particular interest are the author's current studies in Tunicates, and especially his observations made in Sipunculids and Polychætes, where some blood cells reveal intermediate characteristics between leucocytes with inclusions and erythrocytes. A more detailed account of this work may well prove of great value for comparative hæmatology.

\section{FORTHCOMING EVENTS}

Monday, March 31

PALAONTOGRAPHICAL SoctETy (in the Geological Survey Museum, Exhibition Road, London, S.W.7), at 11 a.m.- Centenary Meeting Prof. H. L. Hawkins, F.R.S.: Commemorative address: at 2.30 p.m. $\rightarrow$ Mr. C. P. Chatwin: "The Story of Fossils".

InSTITUTION OF ELECTRIOAL ENGINEERS (at Savoy Place, Victoria Embankment, London, W.C.2), at 5.30 p.m.-Discussion on "Developments in Fractional Horse-Power Motors" (to be opened by Mr. A. N. D. Kerr).

Tuesday, April

SheFfield MEtallorgical Association (at. 198 West Street, Sheffield), at 7 p.m.-A representative of the Mond Nickel Co., Ltd. "Isothermal Transformations".

TELEVISION SocIETy (at the Institution of Electrical Engineers Savoy Place, Victoria Fmbankment, London, W.C.2).-Annual General Meeting.

Wednesday, April 2

Institute of FUel, North-Whatern Section (at the Engineers Club, Albert Square, Manchester), at 2 p.m.-Annual General Meeting. 